\title{
An Interactive e-Participation Model for the Public Administration System in Turkey: SIBIYO
}

\author{
Türk Kamu Yönetim Sistemi için Bir Interaktif e-Katılım Modeli: SiBiYO
}

Naci KARKIN ${ }^{1}$, Hüseyin Serhan ÇALHAN²

\begin{abstract}
The notion of participation has been on the agendas again for supportive mechanisms of political and administrative processes after post-1980 period. Though many factors may be pointed among the possible causes, the growing lack of legitimacy takes the front. It seems arguable and functional that the elimination of legitimacy problem and re-construction of trust towards politically elected ones (Seçilmişler) and bureaucratically assigned ones (Atanmışlar) could be a function of civic engagement for public policy formulation and implementation processes regarding the provision of public services. Therefore, the notion of participation, which is also accused as an ideological repressing tool for the upcoming demands rising from population at large on personalized or organized bases, is at the heart of a universal pervasion process. This text asserts such an actual argument that the notion of participation could be transformed into some other functional forms of electronic means of citizen participation via websites for Turkish public administration system. By means of such an e-participation mechanism, administrative authorities in Turkey could find functional tools by which it is more possible to challenge the political and administrative legitimacy crisis faced with. Through such a mean of e-participation formed over World Wide Web (WWW), population at large can also present their complaints, information, denouncements and proposals to those administrative authorities at local, national or supranational level. In return, administrative authorities can provide the public with better public services in such a way that some obstacles before the notion of participation would be eliminated as time and place.
\end{abstract}

Keywords: Public administration, information acquirement right, e-participation, SIBIYO.

\section{INTRODUCTION}

The history of mankind is separated into three different main phases yielded by three revolutions and transformations happened around (Kocacık, 2003: 1-3). The first of these revolutions was the agricultural revolution whose transformation in the mankind was seemed as the emergence of the agricultural society. The second revolution happened in industry (firstly commenced in Britain) known as the industrial revolution whose main societal and political result was the construction of the industrial society. The last of these revolutions is the informational revolu-

\begin{abstract}
ÖZET
Katılım olgusu özellikle $1980^{\prime}$ ler sonrasında siyasal ve yönetsel süreçlere yönelik yeniden gündeme getirilmiş bir kavramdır. Söz konusu kavramın olası gerekçeleri arasında çok gerekçe gösterilebilirse de, gittikçe büyüyen bir meşruiyet krizinin ilk sıralarda olduğu düşünülmektedir. Siyasal seçilmişlere ve yönetsel atanmışlara dönük meşruiyet krizinin çözümü noktasında vatandaşların kamu hizmetlerinin sunumuna dönük olarak kamu siyasa yapım ve uygulama süreçlerine dâhil edilmesinin oldukça işlevsel olduğu iddia edilebilir. Buradan hareketle katılım olgusunun ki aynı zamanda tabandan gelen bireysel ve örgütsel temelli taleplerin bastırılması açısından işlevsel olduğu iddia edilen ideolojik bir araç olmakla suçlanmaktadır, evrensel yaygınlaş(tır)ma sürecinde olduğu görülmektedir. Bu açıdan, çalışma, katılım olgusunun bir web sitesi uygulaması yardımıyla oldukça işlevsel olacağına inanılan e-katılıma dönüştürülebileceğini savlamaktadır. Çalışmada web üzerinden kurgulanan etkileşimli elektronik katılım kanalı yardımıyla, vatandaşların Türk yönetsel sistemi içerisinde, yerel ve merkezi düzeyde kamu hizmeti üreten kurum ve kuruluşlara şikâyet, bilgi, ihbar veya öneri sunması için gerekli yapısal-işlevsel kanallar ortaya konulmaktadır. Elbette, bir bütün olarak, idarenin de ilgili kanalları dikkate alarak meşruiyet ve devlete dönük güven krizinin aşılması sürecine katkı verebileceği düşünülmektedir. Söz konusu web sitesi uygulaması yardımıyla, katılım olgusunun önünde yer aldığına inanılan zaman ve mekân sorunu ortadan kaldırımaktadır.
\end{abstract}

Anahtar Kelimeler: Kamu yönetimi, bilgi edinme hakkı, e-katılım, SiBiYo

tion (Akman et al., 2005: 239) by which mankind has passed to a new type of society called information society (Almarabeh and AbuAli, 2010: 29) where the attitudes and institutions of the past societal structures have been partially or totally rejected. Called as "information society", what is the most visible in this type of society is the common presence and high level usability of information and communication technology (ICT) devices designed for mass communication and transmission, but also are used for the aim of getting together or making voices louder. As it is well stated by Hassan (2008: vii):

\footnotetext{
' Assist. Prof., Pamukkale University, Faculty of Economics and Administrative Sciences, Department of Political Science and Public Administration, nacidok@yahoo.com

${ }^{2}$ M.Sc. Candidate, Pamukkale University, Institute of Social Sciences, Branch of Political Science and Public Administration, serhancalhan@hotmail.com
} 
"We live in an information society. This much is clear; indeed, this much is acutely palpable. It surrounds us and we are a part of it. We 'know' this society insofar as it constitutes a growing reality that is reshaping the world and what it means to be an individual, a worker, and a member of the public within it. Information technologies based upon computer logic have networked our world, shrinking it to the point where it is possible to be constantly in touch with others, no matter where they are or what time is. The extent of this connectivity is historically unprecedented and it is something that is growing in complexity and utility every minute of every day."

Therefore, this article asserts that the information society is quite functional for the emergence of some citizens who feel himself/herself having duties and responsibilities towards the society in general no matter how they are supposed, or not. In forming such a society functioning on the base of personal participation' and meeting the needs of citizens that could not possibly met by the public administration, ICT devices play quite critical role. The utilization of ICT for this very aim is also functional in producing solutions for the time insufficiency and unity of space $^{2}$ problem, evaluated as the most important by-products of the modernization process. ICT is very functional for opening the ways of citizen engagement for administrative duties theoretically to be carried on by administrators on their own. According to Raban et al. (2011: 375), technology makes it feasible to reach such a society where the people are continuously connected interdependently in all walks of the life, from commerce to education.

It is positively arguable that political parties in power in Turkey starting at the coalition government of Prime Minister Ecevit (1999-2002) have strict inclination for transforming the Turkish public administration system. No matter how being extremely conditional to the (positive, moderate or negative) political climate between European Union and Turkey, Turkish governments seem still enthusiastic on forming necessary legal, political, and administrative infrastructure ${ }^{3}$ for this very aim with the pace provided by the negotiations for becoming a full member to European Union (EU). For this very aim, Turkish government succeeded in provision of various steps for decreasing the level of closeness and secrecy in the administrative processes. Among these steps, the effectuation of legislation related to the "right for acquire information " "in 2004 does worth to be detailed in the following part of the article. Firstly commencing with this legal step, all public institutions are obliged to answer to those information acquirement demands in the fifteen-day duration (informative or documental demands requested by appropriate means or procedures). It should be stated that before this legal arrangement, public authorities were mainly subject to the right to petition required by the Turkish Constitution whose legal duration was sixty days $s^{5}$ without compelling the authorities to give any satisfactory information or document.

Nonetheless, as a deficiency of the Act on the Right of Information Acquirement № 4982, compulsory satisfactory response to the demands was not envisaged by the law makers due to some fears and drawbacks yielded some de facto and also de jure limitations before information acquirement right. One important limitation can be exemplified as of the necessity for "official secret" notion. While the Article 26 of the Turkish Constitution arranges the freedom of expression and dissemination of thought by which is proposed to include some indirect arrangements making the acquirement information possible (Soykan, 2006: 43), the very same article strictly forbids the dissemination of those information classified as the official secret to be defined by the proper procedures ${ }^{6}$. However, since the regarding legislation for the official secrecy has not been passed, the very discrete nature of the state secret still continues to form a barrier before the actual and right implementation of the information acquirement right ${ }^{7}$.

After the entry date into effect of the act on the right of information acquirement ${ }^{8}$, some developments showed the validity of the argument stating political leadership is not only necessary for the legal and political issues but also the administrative ones ${ }^{9}$. In that context, Tataroğlu (2007: 48) asserts it is extremely necessary for political power to take some precautions for the bureaucratic personnel responsible for the protection and management of the information technologies. In addition to that, Yildiz (2009: 428) discusses the necessity of the acceptance of e-government notion by politicians and bureaucrats at national and local levels as vital for the livability and becoming widespread in Turkey. Thus, attitudes of politicians and bureaucrats over the e-government implementation are proposed to be extremely important ${ }^{10}$. However, the functionality and accessibility of e-government applications designed to provide the citizens with the public services are also vital for the e-government applications be accepted by the population at large. For that point, Akıncı \& Çağıltay (2005: 9) drive attention to some visual and technical problems of public institutions' websites as incomplete processes, deficiencies 
regarding visual and content design, the heavy feel of formality, giving one-way information ${ }^{11}$ and making information presenting propaganda in nature as forefront.

\section{AN OVERALL OF TURKISH PUBLIC ADMINISTRATION SYSTEM AND ITS MAIN PUBLIC POLICY STRUCTURE}

As commonly accepted in the regarding literature, Turkish public administration has a centralized structure (Aksoy and Polatoglu, 2003: 435; Polatoglu, 2003a: 54; 2003b: 2) having two basic dimensions: The first dimension is the traditional one that legitimates its centralist ${ }^{12}$ tendency stemming from its historical roots (Aksoy and Polatoglu, 2003: 435). The second dimension is the modern one describing it is in accordance with the Western type of administrative system redesigned in 1923 when the young Republic had been formed. Though Turkish public administrative system has many points in common with those of Western type, it could not succeed in developing a strong tradition of local administration (Polatoglu, 2000: 156) mainly due to its centralist tendencies endeavoring to make the central administration as much powerful as possible for all dimensions ranging from authority dispersion to public service provision.

Turkish administrative system is organized as two main levels. At upper level lies the "central administration", also called as general administration (Kapucu and Palabiyik, 2008:41). At lower level, there are "local administrations" categorized as four inner types. Metropolitan municipalities are said to be the first type of local administrations established in sixteen Turkish cities. They are the strongest local administrations if to be evaluated from the administrative, financial and service provision perspectives. Municipalities, as of the commonly known Turkish local administrations, are the second type of local administrations located in sixty-five cities. Special provincial administrations are the third type of local administration located at the same cities having municipalities. Though located at the same city, besides some other definitive differences, the main difference of the third type from the second type is the boundaries for which the special provincial administration is responsible of service provision. While the third one is responsible for the boundaries of the whole city, the municipality is responsible just for the city center (Mücâvir Alan). The fourth type of the local administrations in Turkey is the village administration headed by Mukhtar and Village Council (i.e. Council of Elders) (Kapucu and Palabiyik, 2008:42).
Besides the central and local administrations, Turkish administrative system includes some supervision and counseling public institutions at central level but outside of the hierarchical effects of the central administration. Some examples of these institutions are National Security Council, Council of State etc. Kapucu and Palabiyik (2008:42) state that the main function of these institutions is providing the Turkish public administration with the counseling or supervising in some specific duties. At the final tier of the Turkish public administration lie the professional organizations upon which the Turkish Constitution bears public legal entity. These semi-public institutions have the aim of preserving the interests of their compulsory members besides actualizing the function of public service provision. Regarding the very important nature of their functions, Turkish administrative system has the aim of controlling them by giving the public legal personality via the Constitution. Some examples of these institutions appear in four types of service sector, namely industrial, economical, health and legal services, as the Bars, Chamber of Medical Doctors, and Chamber of Commerce, Chamber of Industry etc. (Kapucu and Palabiyik, 2008:42).

Kapucu and Palabiyik (2008:21) clearly state that Turkey deserves such a vision that directs her to a greater prosperity and sustainability by utilizing her sources fully by her administrators (politically elected and bureaucratically appointed) with appropriately formulated and applied public policies. It is no doubt that the public policy formulation and implementation regarding the public services in general is designed by politically elected people as a theoretically definitive duty required by the definition of the representative democracy. As of the contemporary counterparts, Turkey is a representative democratic country where the elections at national level are held once a five year period while the elections at local levels are held once a four year period. Therefore, elected people at national level are responsible for the necessary legal regulations mainly the laws at Turkish Grand National Assembly (TGNA - Türkiye Büyük Millet Meclisi - TBMM). As an institutional part of the TGNA, Turkish governments are responsible for the preparation for most of the bills (or draft laws). Although it is theoretically accepted parliamentary members (PMs), regardless of party affiliation, have the right for preparation any bill, it is seen that any draft law without the support of the Cabinet has no chance to be passed. 
As stated above, while the Cabinet is responsible for the design and formulation of the public policies at central level, those appointed ones in bureaucracy are responsible for the implementation of the public policies by means of public service provision so as of the formulated at upper levels. It seems very arguable that the centralist mentality covers all the fields of public policy formulation from very start to end without giving any substantial reference to other actors like local elected ones or non-governmental organizations even if the policy is directly related to them. If the organized actors have no/little effect on the policy formulation, it sounds that public at large will have no place for the phases of policy formulation and implementation in actuality. Since, in theory, people at large should have something to say regarding the public service provision as the sole demander and beneficiary, then, people at large shall be allowed in phases of public policy formulation and implementation. Because the technological tools are very common and functional in gathering the opinions in both public and private matters, they could function well in the process of civic engagement.

At this part of the article, public policy formulation and citizen engagement issues are to be addressed. As commonly known, the classical theory for public policy analysis states that public policy process is realized via various means of stages upon which different actors take part in (Çevik, 2004: 141143). These stages or processes start from the phase of agenda setting to the phases of policy implementation and evaluation (Kaptı, 2011: 24). At these stages, though many actors take part in, the elected and the appointed ones play the most crucial role regarding the decision-making process. However, if the public policy can also be defined as the decisions and priorities regarding the provision of all public services, the role of the population at large has to be addressed, no matter being organized or personalized. At the classical approach to the public policy analysis, the importance of role of the population at large is generally proposed at the phase of agenda setting (Demir, 2011: 111). At this phase, as required by the representative democracy and bureau-maximization approach, if the politically elected(s) endeavor to be in power (for the first time or again), they have to collect the demands from their constituencies especially at the pre or post election times. No doubt on the fact that the demanding process is not solely on the times of election but it is feasibly arguable that the kindness and responsiveness of those to be elected at its peak level in the election times.
Regarding the classical theory to the public policy analysis, there are actors that taking part in the stages of the public policy formulation and implementation. Some scholars like Ergun (2004: 305) assert a difference between official and unofficial actors of policy making processes. While stating political parties, pressure groups ${ }^{13}$ and population at large, he differentiates between first tier of official actors as of those executive, legislative and judicial powers of the state and the second tier of the official actors as public administration in general. Some others like Çevik (2004: 147-156) adds media as an important factor in the public policy process due to its dissemination capability for nonfunctional/misuse public and private facts.

\section{THE INTERSECTION BETWEEN PARTICIPATION AND E-GOVERNMENT: E-PARTICIPATION}

The political side of the classical citizen and state dilemma is as obvious as the administrative one when it is evaluated from its continuing tension stemming from the regarding history. As a universally well-known phenomenon, lack of legitimacy could be accepted as the main political problem that all the countries face with in present time having its roots in the past especially those of World Wars (WW). Wang and Wart (2007:265) cites that lack of legitimacy towards the states could be evaluated as a result of WW II.

Hence, it is arguable the lack of legitimacy is among the present big troubles all the governments must solve whatsoever regardless of ideology or government type. Even the most democratic governments are expected to yield various practices for solving the legitimacy issue including increased level of citizen participation. As among the causes of such a lack, Wang and Wart state some reasons as increased cynicism in public, shortcomings and scandals of governments, disaffection of people by the expansion of states resulting in distance in public policies and citizen disappointment in the performance of the governments regardless of legislation, execution or judiciary powers in particular (2007:265).

In that framework, as a broader sense of participation concept, the governance notion that is appreciation of the citizens as partners not subjects in both political and social spheres can serve as a beneficial instrument for solving the legitimacy problem among others. For this very aim, over the past 20 years, according to French and Bailey (2011: 241), major democracies have sought means and ways for consulting or involving the citizens at large in the 
processes of decision making and implementing by which collaborating the elements of deliberative democracy into representational liberal democracies.

Since the involvement of the population to the public policy formulation and implementation process without regarding and necessary information provided is fully nonsense, then the position of governments for providing the citizens with the necessary information seems extremely crucial. As also noted by Mayer-Schönberger and Lazer (2007: 1) with some emphasis on the exaggerated role of e-government:

"Information is the foundation of all governing. Information guides decisions and processes large and small-from matters of war and peace to garbage collection. The last decade has witnessed unprecedented attention to the machinery of information in government-often categorized as "electronic government." Information and communication technologies have been touted as the cure for everything from the rigid, silo-based architecture of government to the sagging rates of participation in our democracy. However, too often the focus of electronic government has been on technology - on the technically possible-rather than on the flows of information. "

However, it should be directly noted that the provision of the participation notion is not solely a function of legal or administrative measures taken or to be taken. It has its core roots in the socio-cultural traditions and structure of any society where the participation should have its roots whatsoever. It is arguable that the measures to be taken by the elected and the assigned together with the ICT tools have the possibility of broadening the term but not for direct generating. Regarding the political context of the participation notion, Yeşilorman (2006: 1) asserts that politicization is a societal formation upon which those socio-cultural factors not carrying political dimensions have their effects as well as of those factors political character in nature. Similarly, Altan (2011:313-315) quotes that the political participation is affected from various factors ranging from education to socio-economical conditions. No doubt that these factors can be categorized as dependent and independent according to the fact that they are in or out of reach of the concerned person in the related participative processes.

In order to expound this argument, it is necessary to get back to the discussions regarding the neo-liberal thesis emerged at the 70's. In the context of second big crisis that capitalism faced with, the social welfare state proposed by Keynes was criticized $^{14}$ mainly by the ideas and opinions generated in Anglo-American culture especially by those neoliberal ones of Anglo-Saxon traditions. For such an aim, budget, performance and trust deficits constitute the basic commencing points to criticize the economic and administrative tools of post-war welfare state. Some policy proposals as transparency, accountability and participation are prescribed for curing these deficits (Kettl, 1998: vii). If these proposals are regarded as neutral measures without considering its ideological roots ${ }^{15}$, the e-government applications are believed to serve as utmost functionality especially for those two policies as transparency and participation.

All these precautions and methods are presented in framework of a new conceptualization known as (new) public management approach. Since (new) public management approach and its derivatives provide the politicians with an important theoretical base for the transformation process of public administration systems. This conceptualization and its derivatives have strong effects on public administration practice not only in Turkey but on most of the countries no matter being developed, or not.

The definition of participation represents an understanding which includes the engagement of the citizens (not personally but at an organizational basis) to the process of decision taking as partners. Such an understanding requires an environment where the traditional paradoxical dichotomy dictated by classical administrative theory between the two parties of administrative process as citizen and state is thawed. Finding its conceptual generative roots in 1800's at the activities of local administrations in Europe, it is undeniable that the reborn of participation concept is parallel to the post-war welfare planning policies. However, the broad use of the participation term is conditional to the neo-liberal policies being forwarded after 70's as a critique directed to the post-war welfare economics. Nonetheless, it is possible to adapt the concept to the domestic conditions in the facets of time and space. Regarding the solution to the lack of legitimacy all the present governments share, the participation concept presents universal functionality if connected to those policy instruments like transparency and accountability. If Holtzman's (1989) model of decision process is taken as a base, French and Bayley (2011: 242) assert that participation process gains its actual meaning. They distinguish the term participation from the terms of instrument, mechanism or technique by arguing 
that the participation concept must comprise a combination of the terms of instrument, mechanism or technique in such a way that public at large or selected stakeholders be ended with a decision made (2011:242).

Regarding the notion in Turkish case, the Special Expertise Committee Report on Local Administrations prepared at the framework of 8th. 5-Year Development Plan by State Planning Organization ${ }^{16}$ (SPO) (Devlet Planlama Teşkilatı - DPT) takes the participation concept as its widest comprehension. The report assumes the citizen participation not only as the engagement in decision taking but also the control/audit function born on citizens at large. The report also proposes some new mechanisms regarding the accountability of the local administrators towards the public at large. It is extremely remarkable that this type of accountability is far away to be regarded in the boundaries of traditional accountability of politicians before public at large (or accountability of politicians and bureaucrats before the courts).

It should be noted that the actual realization of the participation concept with the full engagement of the population at large is possible with the utilization of ICT devices, especially the web and the mobile ones. Therefore, it is necessary to discuss the notions of e-government in detail. It is very clear that there is a chronologically close connection between the dispersion of internet with the development of e-government definition. Since e-government being the main concept, some other related concepts as e-democracy, e-participation, e-governance etc. emerged after and in connection with the term e-government. Yet, Löfstedt (2007: 101) states some sub-domain terms of e-government as e-Participation, e-Administration or e-Democracy.

Conceptually, Almarabeh and AbuAli (2010: 29) argue e-government is the realization of the idea of Al Gore (former US Vice-President of Clinton Administration) who envisaged an automated environment where citizens and government to be interlinked to each other. Yet, e-government concept has gained its widespread usage later than that of private sector concept as e-business concept but before than those of public sector concepts such as e-municipality (Moon, 2002: 425). Even if different definitions of e-government appear in the literature since e-government is conceptualized by taking the relative theoretical background as a base (Hu et al., 2009: 971), there are some points that all the definitions share in common. Among them, the informati- on technologies mostly exemplified by the internet, citizen participation, informational and documental dissemination, and online actualization of public services take the front. No matter how hard to find one and only definition of e-government in the literature, it is necessary at this point to give a definition of e-government. In this framework the definition of e-government can be stated as;

"e-government with its widest meaning is the safe and non-stop execution of the duties and services assumed by state and those of citizens in the electronic environment on a mutual basis regarding relationships between the public and state in the contemporary societies" (Arifoğlu et al., 2002: 12).

Theoretically, serving the people with electronically driven means is among the aims of e-government. This aspect of the e-government notion is in accordance with the narrow opinion of e-government stating an online transaction of the citizens with the government (Mayer-Schönberger and Lazer, 2007: 3). If the online interaction of state with its citizens is taken as one and only aim, some other essential parts of the notion remain unfulfilled. The technological transformation in the provision of public services gets its main meaning by the principle of congruity, i.e. the responsiveness of public administration to the changes emerging around. Achieving in that part can be evaluated as the most common known dimension of e-government concept. However, thinking e-government concept only as the technological transformation of public service provision on single or differentiated portals ${ }^{17}$ will diminish the importance of e-government concept. The real meaning of e-government must be the preparation and presentation of necessary conditions for an appropriate environment where citizens can participate in the decision making process as partners not as subjects as in the past. In other words, the ultimate aim of the e-government materializes itself by the acceptance of the citizens as partners next to the classical actors (politicians and bureaucrats) for the decision making process. What is definite on this environment is the expiration of old and traditional administrative behaviors with its bureau-pathological dimensions ${ }^{18}$. E-government and its functions around the concepts of equality, participation, transparency, and civil society seem more meaningful. Since it is the unique dimension by means of which is possible to recover the state from its some negative and bureau-pathological perceptions, it is argued here that the most important event upon which the discussion is built is the ideological not the technolo- 
gical one since it is believed that the e-government presents quite productive ground where administration can wipe those old and corrupted mentality and institutionalized structures out ${ }^{19}$.

Such a deep transformation is simply possible on the condition that the administration must invent new procedures and means of citizen engagement in the decision taking and application processes. Among the present facilities of participation around the e-government applications, it is possible to count Geographical Information Systems (GIS) based technologies, web sites and their contents like forums, on-line chats, online form fulfilling and the digital map based software or web site interfaces like this article proposes.

Right to petition, right to acquire information, Communication Center at Prime Ministry (Başbakanlık Iletişim Merkezi - BIMER) take the front in the queue at central administration level if the legal, administrative and political tools deployed by the administration in Turkey regarding the citizen participation are on concern. Local administrations, apart from the tools designed by the central government, build public affairs bureaus called white desk or blue desk $^{20}$ and have some widespread efforts to develop one-way means and procedures by which local people can easily get in touch with the local authorities without participation.

The Prime Ministry of Turkey issued a circular (2004/12) on "The Utilization of Right to Petition and Right to Acquire Information" for making these rights functional and making the public authorities be stimulated to respond to the demands coming from the citizens in an appropriate way. In this Prime Ministry Circular (PMC), it is strictly stated that the applications of citizens on the subjects of wishes, proposals and complaints related to public spheres and the utilization of rights to petition and acquiring information about the related topics must be regarded as the requirements of a democratic and transparent administration built upon the principles of equality, neutrality and transparency.

The concerned PMC considers that the administration behaving in a sensitive manner to the personal rights and freedoms as the basic qualification of state of law if the intersectional axis of rule of law, democratization, and transparency are taken granted as a mutual base. For that very aim, the circular points out that the government behaves in a manner prioritizing the citizens' needs and wishes. By means of regarded PMC in question, government reminds the bureaucrats how the citizens' rights be arranged in the Constitution in such a way that government attracts all the attentions to one of the basic duties of the state, namely, the maximum solicitude over the utilization of the citizen rights.

Besides the related PMC, it is necessary to talk about the Evaluation Board for Information Acquirement (EBIC-Bilgi Edinme Değerlendirme Kurulu $B E D K)$ established at Turkish Prime Ministry. The vision and the mission of the board are stated at its website as:

"...The Evaluation Board for Information Acquirement has been established as a requirement of the Article 14 of the Act on the Right of Information Acquirement for the aims of examining the decisions given by the regarding public authorities as a result of the applications made to them and producing decisions regarding the usage of right for information acquirement... Its vision is to make an addition to the emplacement and growing up of the principles of equality, accountability, neutrality, and transparency in the public administration as a requirement of a democratic and transparent administration..."

$E B I C$ is also functional in overall evaluation of the results regarding the applications to the information acquirement right. As required by the Provision 44 of the "Regulation on the Essences and Procedures regarding the Implementation of the Code on the Right for Information Acquirement", administrative authorities have to send the annual reports regarding the implementation of the Code № 4982 to the EBIC. After making an overall evaluation, EBIC has to send its annual report to the TGNA. As of the last report of EBIC for the year 2010, the overall result is shared by the TGNA with the citizens. According to report, the overall numbers are shown in the Figure 1. However, as also stated by EBIC, the total number of applications was 1.446 .823 in actual, but 93.203 applications was re-directed to the regarded administrative authority.

It will help to clarify the case what is the actual situation for the right for information acquirement by picking some administrative authorities up. First of all, the overall information acquirement data of the Turkish Armed Forces submitted by the Turkish General Staff (Genelkurmay Başkanlığı) in 2010 stated that the number of the total applications was 10.476, 7.901 out of which was positively replied by allowing acquirement to information or to documents. 117 applications were partially positively or partially negatively replied and 1.266 applications were rejec- 


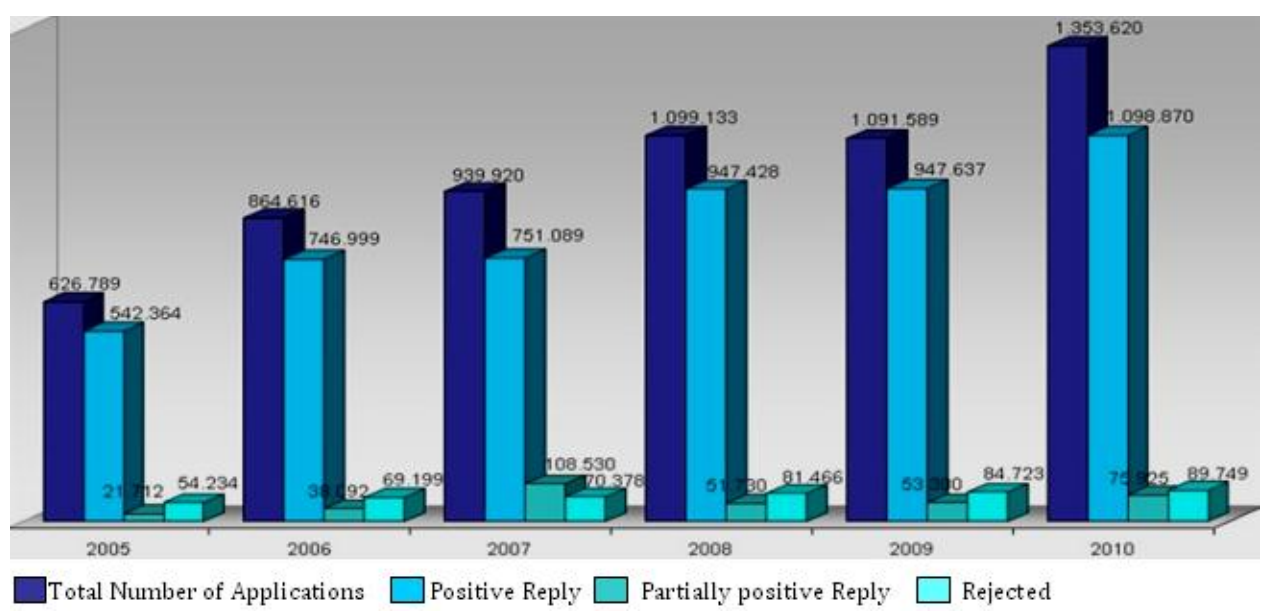

Figure 1: The Dispersion of the Information Acquirement Applications to the Public Authorities in the Range of 2005-2010 (http://www.bedk.gov.tr/genel-raporlar.aspx)(10.09.2011)

ted. 77 applications were replied by excluding the official secrecy dimensions. 1.115 applications were redirected to the regarded administrative authority by General Staff of the Turkish Armed Forces (TBMM, 2011: 5).

Secondly, as of the overall picture of 2010 regarding the economical sector which is represented by the State Ministry headed by the Vice-Prime Minister Ali BABACAN, it is seen that the number of the total applications was $91.279,75.634$ out of which was positively replied by allowing acquirement to information or to documents. 401 applications were partially positively or partially negatively replied and 14.522 applications were rejected. 172 applications were replied by excluding the official secrecy dimensions. 550 applications were redirected to the regarded administrative authority by the State Ministry (TBMM, 2011: 6).

Thirdly, in order to show the present information acquirement data for those matters regarding the diplomacy or foreign affairs represented by the Ministry of Foreign Affairs (MoFA). It is seen that the number of the total applications to MFA was 10.198, 9.002 out of which was positively replied by allowing acquirement to information or to documents. 625 applications were rejected. 571 applications were redirected to the regarded administrative authority by the related Ministry (TBMM, 2011: 12).

In order to show the present information acquirement data for those matters pertaining the internal affairs represented by the Ministry of Internal Affairs (MolA). From the regarding data, it is clear that 29.342 applications in total had been made to MIA, 24.093 out of which was positively replied by allo- wing acquirement to information or to documents. 734 applications were partially positively or partially negatively replied and 3.354 applications were rejected. 14 applications were replied by excluding the official secrecy dimensions. 1.147 applications were redirected to the regarded administrative authority by the related Ministry (TBMM, 2011: 6). In total, 28 applicants suited the Ministry before the administrative judiciary.

As an example of matters pertaining to justice, the overall looking of the information acquirement applications to the Ministry of Justice is as follows: the number of the total applications was 18.228, 12.282 out of which was positively replied by allowing acquirement to information or to documents. 513 applications were partially positively or partially negatively replied and 1.649 applications were rejected. 47 applications were replied by excluding the official secrecy dimensions. 3.737 applications were redirected to the regarded administrative authority by the related ministry. 4 information demanders suited the ministry before the administrative judiciary (TBMM, 2011: 6).

By giving some examples of applications to administrative judiciary, it will be functional to give the overall picture of whether demanders follow the path by application to EBIC or the path to applying to the administrative judiciary is shown in the Figure 2. It is clear that if the application to acquirement to information is rejected by the regarding public institution, the applicant or demander chooses the path towards the EBIC mostly. 


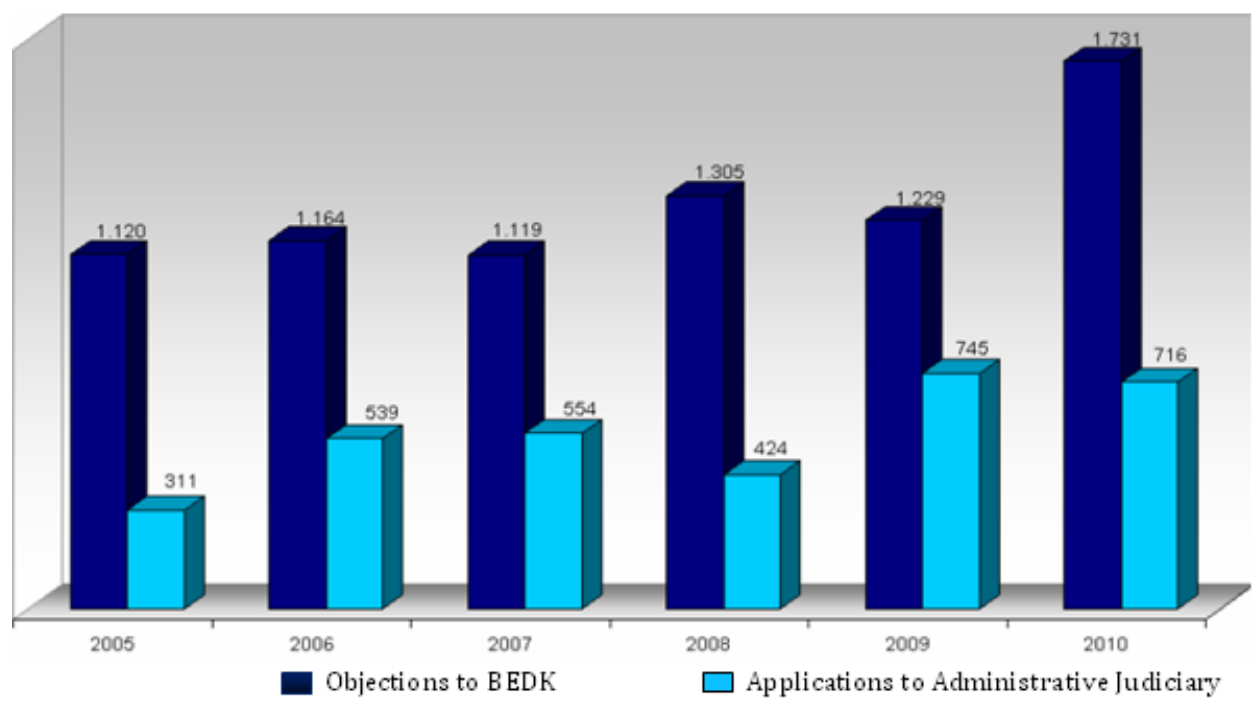

Figure 2: Channels for Re-applications for Rejected Information Acquirement Demands (http://www.bedk.gov.tr/genel-raporlar.aspx)(10.09.2011)

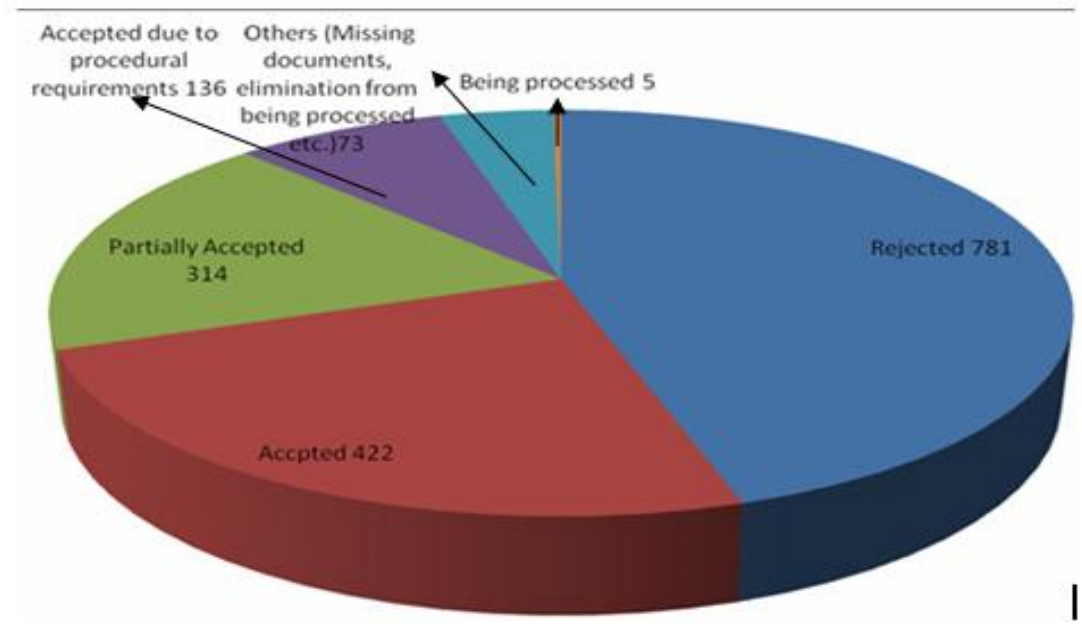

Figure 3: The Evaluation Board for Information Acquirement (EBIC) Decisions in 2010 (http://www.bedk.gov.tr/genel-raporlar.aspx)(10.09.2011)

By applying to the EBIC does not provide the applicant with the desired action to be fulfilled since it is clear from the Figure 3 that the EBIC also rejected those applications which have already been rejected by the regarding administrative authority before it was carried to EBIC. The overall picture of how re-applications to EBIC be resulted is not a guarantee for the application to be resulted in the desired information or document be acquired.

In Turkish legislation, citizens' recourses to the administration have been arranged around the Articles $^{21} 26,40$ and 74 of the Turkish Constitution. Due to requirements of the constitutional provisions, related implementation acts were legislated regarding how these articles would be put into practice. In that context, it is possible to list some of the implementation laws as "The Act on the Utilization of the Right to Petition" (passed into law on November 1, 1984, Code No 3071) in the first instance. Other laws seem as the "Act on Right of Information Acquirement" into law on October 9, 2003, Code No 4982), "The Act on the Establishment of Public Ethical Board" (passed into law at May 25, 2004, Code No 5176), Draft ${ }^{23}$ Law on the Acceleration of Public Services (March, 2010), Draft Law on Official Secret (October, 2011).

Though the right to petition ${ }^{24}$ is extremely important, this article draws the attentions to the legislation for the information acquirement due to some deficiencies that right to petition includes as it proposes a one-way process between the citizen 
and the administration, and it consists of many troubles regarding the implementation. The legislation regarding the information acquirement in Turkey has been started with the "Act on Right of Information Acquirement ${ }^{\prime 25}$ Code $N^{\circ}$ 4982. The Act states its aim in its first article as:

"The purpose of this Act is to lay down the guidelines and procedures for individuals to exercise their right of information acquirement in accordance with the principles of equality, neutrality and openness which are the fundamentals of democratic and transparent administration".

The Act covers all the activities of public institutions including those professional organizations having the legal public identity by reserving the provisions of the "Act on the Exercise of Right to Petition" ( $N^{\circ}$ 3071) effectuated in November 1, 1984. The act states all the public institutions are obliged to take the necessary administrative and technical measures to meet the applicants' ${ }^{\prime 26}$ all kinds of information or document demands (with some drawbacks and exclusions) in an effective, swift and accurate manner. Regarding the application procedure to the public authorities, the act clearly specifies the manner in Article 6 as:

"The application to acquire information shall be made to the institution or organization where the requested information or document is kept, with a petition comprising the name of the applicant, signature, domicile or business address. If the applicant is a legal person, the application must contain the title of the legal person, address, and the signature of the authorized person and the certificate of authority. The application can be made in electronic format or by other means of communication on the condition that other information to identify the person's identity and signature or from whom the letter originates can be legally identified. In the petition, the information or documents requested must be clearly indicated."

Hence, the application ways and procedures possible seem as the application on paper, and online forms designed to send the application as e-mail. Online forms as tools produced by ICT deserve special attentions since it provides the applicants and public authorities with the continuity and regularity theoretically possible in the literature. Although the Act on Right of Information Acquirement is an important advancement for the administration to be democratic, participative and transparent by its essence, however, there have to be wisely designated precautions for the proposed system to perform in accordance with the effectiveness, efficiency and supervision since the administrative authorities will respond to the applications about themselves.

\section{THE ROLE OF DIGITAL MAPS IN THE FRAMEWORK OF E-PARTICIPATION CONCEPT}

A digital map is defined as the computerized display of any geographically referenced information possible (Jones et al. 2004: 91-107) and plays important role in the e-participation mechanism that this article proposes. Although the usability of digital maps has increased to a significant variety, they are occasionally used in GIS applications or urban information systems in terms of e-government concept, this article draws attention to the possible functionality of digital maps for citizens to take part in e-participation process.

As commonly known, media is extremely functional in delivering the citizens' wishes, complaints and proposals to the related administration at both local and national levels by means of dysfunctional working of some public authorities. However, there must be clear and direct ways for the citizens to delivering their wishes, complaints or proposals to the public authorities. As it is seen in case example of SIBIYO, the people can deliver their complaints or demands ${ }^{27}$ to the authorities in local or national levels without a need for some legal regulations on a joint portal for shared and commented by third parties. Before going ahead to make SIBIYO model detailed, it would be a necessity to present the BIMER case that is somehow likewise the SIBIYO case in some aspects.

As a sample model of e-participation practice in Turkey that attracts the attentions concerning the e-participation at both local and central levels is BIMER. Proven itself to be the most successful application of traditional public relations notion, BIMER formed an obligatory information acquirement application corridor for all the public administrative authorities in Turkey with a PMC on BIMER No 2006/3 published in the Official Gazette No 26055 in November 11,2006 . By stating the fact that the governance and participation concepts took over in the related literature, regarding PMC proposes a system where citizens deliver their wishes, complaints and proposals in a fast, efficient and safe manner. The regarding circular gives much attention to the processes of taking, evaluating and responding for complaints, wishes, proposals and demands as immediate as possible. In the PMC, it is taken for granted necessary and crucial that some novelties must be implemen- 
ted in the public institutions regarding the concept of public relations. As argued by Canöz (2008: 141) public relations are to be regarded as among the responsibilities of all the organizations towards their surroundings if they aim to eliminate or minimize the negative aspects produced.

For a brief critique of BIMER case, it should be firstly noted that the present functionality that produced an effectiveness and efficiency regarding the information acquirement via BIMER has to be connected with the very personality of Prime Minister Erdogan. Hence, it is a reality that any implementation connected with the personalities whatsoever have no continuing effect. Yet, being an implementation by which citizens reach the most influential political position regarding the Turkish administrative system augments its functionality. No matter how it is imaged as a tool for e-participation, like the other local and national means of participation, BIMER is a case of classical principle of public relations since it is regarded as so by the regarded PMC and it envisages just one-way mechanism by not clearly sharing the applications with the third parties related.

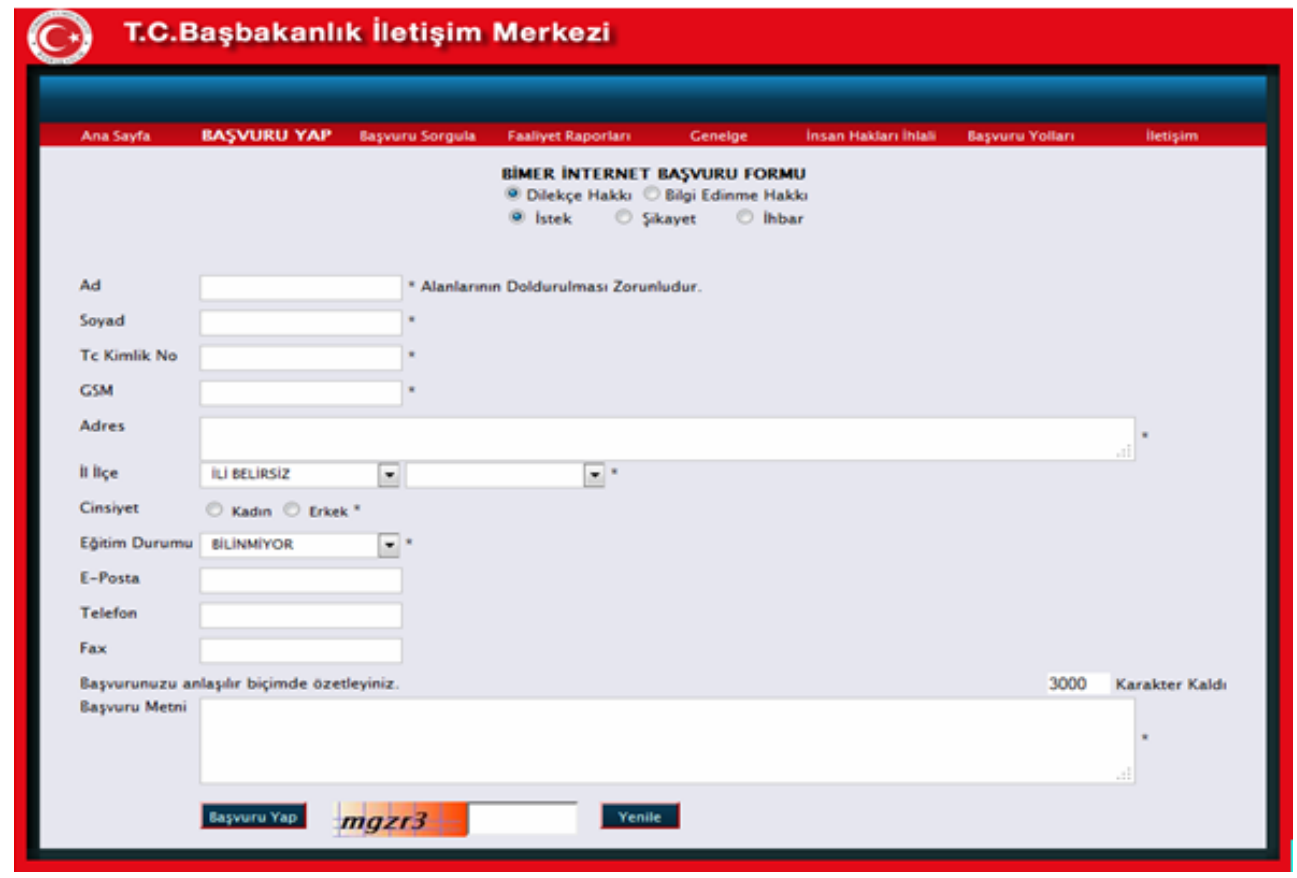

Figure 4: BIMER Interface

As to be seen in the July - 2011 monthly activity report of BIMER (since it is the last of the present activity reports as of November 2011), it is stated that BIMER concluded 2.192.590 applications in total at the period between the years of 2006-2010. The details of applications made through the BIMER Center in July-2011 seem as of the following tables below (http://www.basbakanlik.gov.tr/Forms/Bimer/Docs/ Temmuz2011.doc):

On the other way, in case that the BIMER web page is technically examined, it is clearly visible that the form in the main application page has an extremely simple interface (Figure 1). If the applicant requires the administration to reply his/her application back, it is compulsory to give the essential personal information (i.e. the numerical citizenship ID Number) which makes ease to identify the applicant by any means if necessary. Although BIMER model is quite successful regarding the statistical information given in the main page, yet, it does not eliminate the need for some other more functional website applications like SIBIYO.

Since the notion of participation in local governments is shaped around the traditional notion of public relations ${ }^{28}$ likewise of the central level, the common and important argument in the SIBIYO applications is its potentiality rising up the participation. For example, the applications in the web pages of the municipalities are not shared with the third parties. Therefore, it is not possible to make any comments by others visiting the website for any reason. For that reason, SIBIYO model allows the people to share information (with visuals if necessary) and comment by third parties on the applications made and shared. 
Table 1: General Dispersion of Applications (Apps.) Via BIMER

\begin{tabular}{|l|c|}
\hline General Appearance of the Applications & July - 2011 \\
\hline Personal Applications (by face to face application) & 302 \\
\hline Via Internet Applications & 41.763 \\
\hline Written (by regular mail) Applications & 3.808 \\
\hline Applications by Phone & 2.381 \\
\hline Applications by e-mail & 7.878 \\
\hline Applications by Fax & 68 \\
\hline Applications by Information Acquirement & 1.096 \\
\hline Total & 57.296 \\
\hline
\end{tabular}

Table 2: General Distribution of the Processed Applications (Apps.) Via BIMER

\begin{tabular}{|l|c|}
\hline Dispersion of the Processed Applications according to the Institutions & July - 2011 \\
\hline The Number of Processed Apps. at Prime Ministry* & 53.514 \\
\hline The Number of Processed Apps. at Ministries & 25.712 \\
\hline The Number of Processed Apps. at Governorships & 22.714 \\
\hline The Number of Processed Apps. at Municipalities & 1.861 \\
\hline Total & 103.801 \\
\hline
\end{tabular}

The concept of SIBIYO is a Turkish abbreviation of some words as complaint (şikayet), notification (ihbar), information (bilgi), demand (istek), help (yar$d ı m$ ), and proposal (öneri). It is proposed to be an interactive e-participation model designed for increasing the participation of the citizens in the decision making process regarding the provision of public services. In this e-participation model, it is proposed to share and discuss the details of any application from the very start to the final end on an internet portal ${ }^{29}$. As an interactive application on Google Map base $^{30}$, SIBIYO aims to point out the applications over the digital map. For the aim of easiness to point out the actual addresses of the users, online Google Map system is preferred. By means of Google Map, there emerges no need to give the details of the addresses of users or made applications whatsoever. As commonly known, users have the chances to share the visual elements like photos or videos regarding the applications in the regarding map system. Hence, such an application or information share process will provide especially local public entities with the differentiated point views other than that of theirs regarding the local issues. Addition to that, citizens would be able to evaluate the performances of public institutions regarding the local subjects.

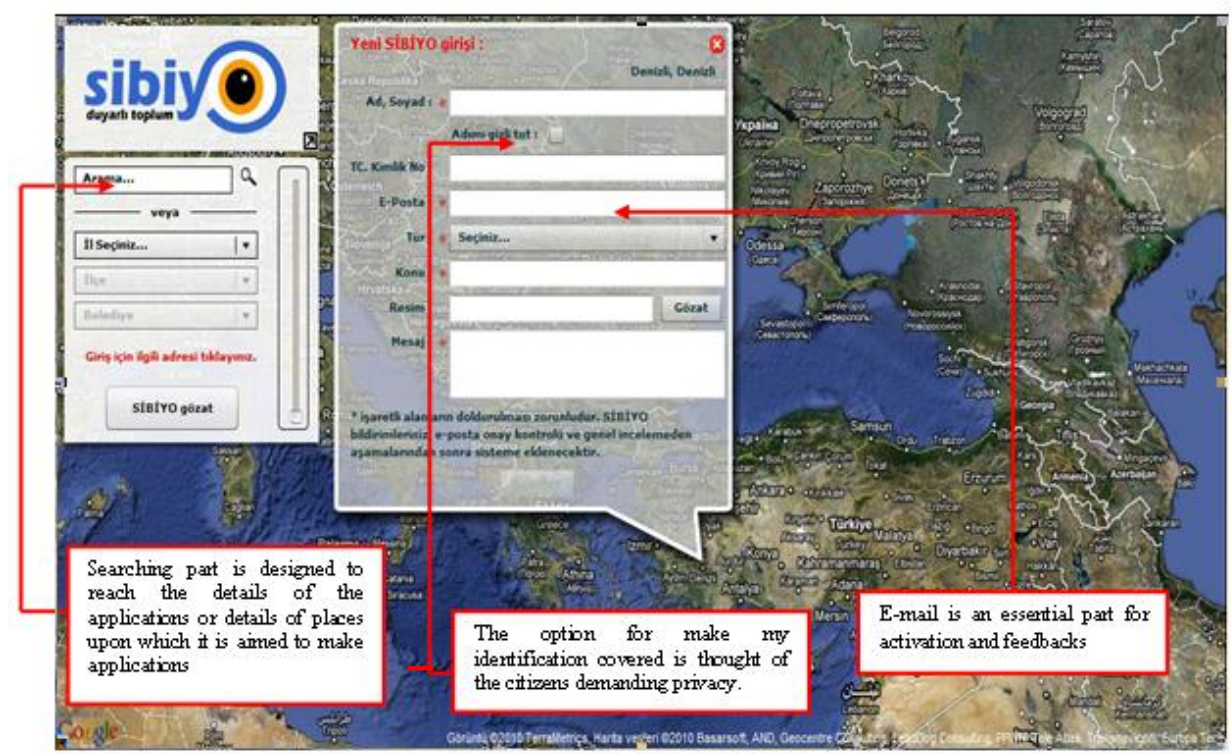

Figure 5: SIBIYO Application Interface and Form

The searching part is used to reach the places or make applications. Instead this option, picking up sub options for city, districts or municipality boxes can be used. In addition, the user convenience of Google Map is on the website. 


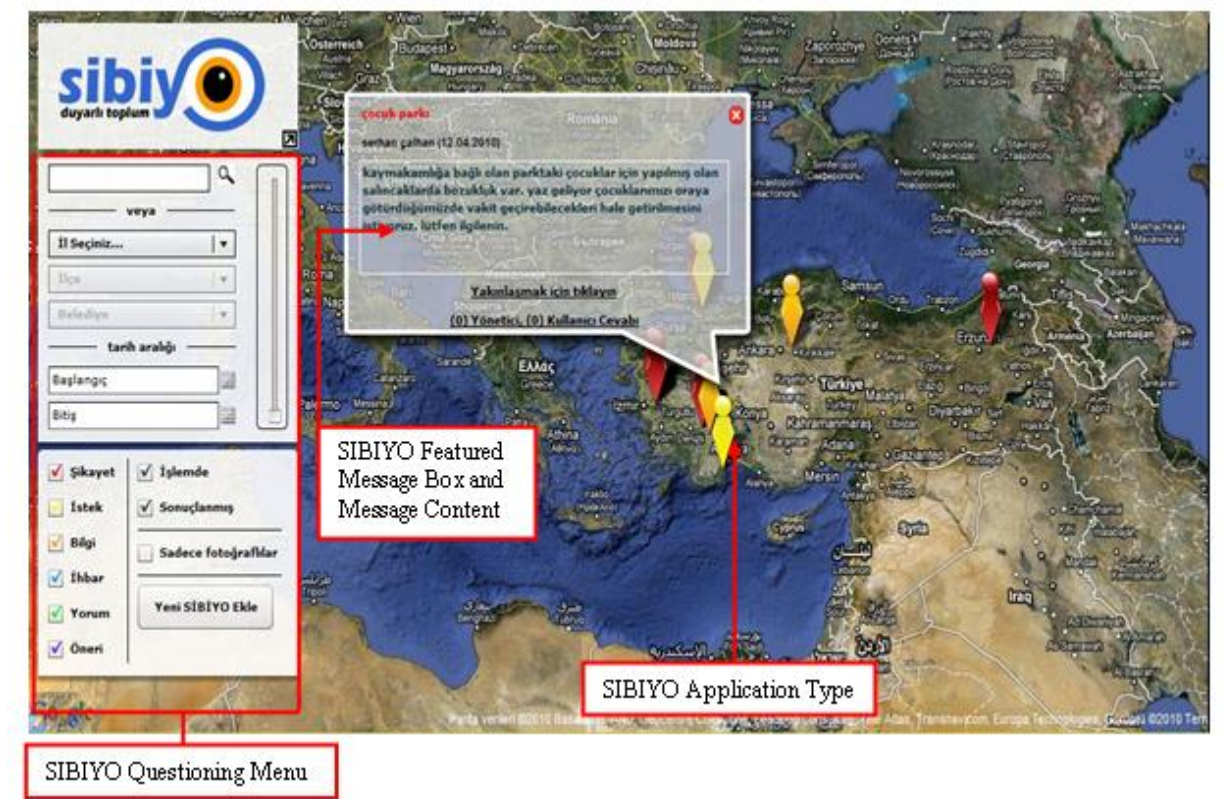

Figure 6: SIBIYO Monitoring Page

In SIBIYO questioning menu, SIBIYO entries can be questioned separately according to the type including the options like data whether having visual elements, or in process or concluded or not. In the SIBIYO message box, applications are issued after accuracy confirmation regarding address, content and message conformity. In this box, by tapping the statement "tap for approach" it is possible to come close to the map place of the observed message. By doing that, it is possible to visualize the admin message, or comments related.

\section{CONCLUSION}

It is very sound to argue that there has been a lack of legitimacy in the relationship of citizen with the state for some time started in the times of wars. As a universally well-known phenomenon, lack of legitimacy could be accepted as among the main problems that all the countries face with having its roots in the past. Wang and Wart (2007: 265) cites that this lack in the legitimacy towards the states could be evaluated as a result of WW II. Hence, it is arguable that even the most democratic administrations are expected to yield some means for solving the legitimacy issue including increased level of citizen participation, also known as civic engagement. It is also a well-known phenomenon that the ICT devices are well-spread and common in use. Motivating from such an intersection of legitimacy problem, a need for increased civic engagement and the spread of ICT devices, it is proposed that ICT tools can be extremely functional for the provision of supportive mechanisms against the elimination of legitimacy lack by increasing the citizen participation in public policy process to an extraordinary level that will be called as e-participation. Hence, this article presents an e-participation model by using an ICT tool, website, for Turkish public administrative system called as SIBIYO where public at large can submit their complaints (şikayet), notifications (ihbar), information (bilgi), demands (istek), help (yardım), and proposals (öneri) via the website.

ICT brings a transformation not only for the societal institutions but also for those of political ones. Notably commencing at the last decade, governments have been using the Information and Communication Technologies (ICT) in administrative and political spheres at increasing ratios to improve their own performance (Lee et al., 2011: 444) to increase the quality of public services. Similar to those contemporary counterparts, Turkish government reveals an enthusiasm to transform its public administration system by adopting or inventing some techniques and mechanisms characterized by ICT's for the sake of minimizing the processes and actions including secrecy and closeness ${ }^{31}$. As scholarly known, secrecy and closeness were used to be among Turkish public administration system's main historical characteristics (Sezer \& Karkın, 2002: 210212) which prevent the public at large from being a stakeholder for decision taking and implementing processes. By means of such attempts, Turkey can be assumed to hold an aim for reaching a participative level of public administration system where the notions of transparency and accountability could form the base. 
This article tries first to make an evaluation regarding the right for information acquirement process by examining present legal and administrative tools and their implementations in Turkish administrative system. After making the regarding evaluation, this article presents an information and data system model called SIBIYO designed for producing additional tools to those of central and local administrative ones in order to increase the citizen participation believed to be a supportive mechanism for the elimination process of legitimacy lack. The SIBIYO model intends both local administrations and institutions pertaining to the central administration to make the citizens involved in participation for solving some problems pertaining to the provision of public services. It is argued that through such a model embedded in ICT in general and in internet in particular, local and central administrative institutions will have the possibility to share some public policy issues with the public at large by means of complaints, information, demands and proposals regarding the public services. In SIBIYO case, it is designed that the citizens are to be participated regarding better provision of public services by data entry in this system for the stimulation of the administrative institutions.

Being a societal support for the urban life, SIBIYO system has been designed as a wide infrastructure open for all the citizens primarily for those who live in urban places. By that system, it is possible to broaden the participation concept in electronicallydriven sphere by providing the citizens with the blissful, constructive and proposing solutions for developing a preventive or supportive public service comprehension. In addition, by SIBIYO system being a bridge between the citizen and administration, local and central administrators shall have the possibility to involve at the public sphere without taking in physically.

No matter how different targets keeping at the background, the political party in power effectuating the act on the right of information acquirement is in a position where not only the applicant who demands document or information is sufficient for the process to keep going but also the bureaucracy has some positive or negative effects on the ongoing processes. In order to proceed beyond the so-called problem regarding the effects of the bureaucracy, $\mathrm{BI}-$ MER presents reasonable functionality for both citizens and public administration in general. However, regarding application includes some negative dimensions. Since it is an application institutionalized at the central level, most of the local administrations do not approve the third institutional parties rather than themselves to learn their problems. Besides, the outer institutions other than the related institutions may prolong the solution process. Therefore, especially local administrations keep an online form mail at their websites, which is also required by law, in order to collect the applications like complaints, demands or proposals. No doubt these independent form mails present valuable functionality for gathering the applications of citizens regarding the urban life at the citizen-administration interaction but it is not rationale that these independent, uncontrolled, one-way and disjoint tools decrease the need for an integrated system or applications by which citizens can participate directly for the urban life problems. 


\section{END NOTES}

${ }^{1}$ The article asserts the emergence and importance of the participative mechanisms that are not necessarily functional on the organized base. As it is commonly accepted, the mechanisms for organized participation are still present in the societal, administrative and political processes, some of which is under guarantee of the law. However, what the information society or tools of ICT makes possible is the emergence of participative mechanisms functioning on personal base. It is believed that it is the most crucial part of the transformation that information revolution yielded for the political and administrative processes.

${ }^{2}$ It should be noted that the participation without ICT tools requires the unity of spaces where the people and the processes realized at the same time at the same place.

${ }^{3}$ Prime Minister Erdogan reminds the bureaucracy that his government gives extreme importance to the empowering those binds between the state and society in the Prime Ministry Circular No 2004/12. Therefore, he assures the bureaucrats on the fact that responsibility of his government to the expectations of the public at large confirms the basis of their politics.

4 The theoretical root for right to acquire information comes from the Turkish constitutional article (Article 74 Right of Petition, Right for Acquirement Information and Application to Ombudsman). As given by Anameriç (2004: 168) the codes regarding the information acquirement are in effect in 50 countries approximately.

${ }^{5}$ According to Soykan (2006: 26-28), there is a need to clarify the some basic differentiation between the right to petition and the right to acquirement to information. She argues that petition to right is defined in the Constitution as a "desire, objection or complaint" in the context of application to administrative authorities. However, since the appeal process is not assigned in the Constitution or regarding legal or administrative texts, the administrative authorities have the rights to reply just by saying "nothing" in essence. Therefore, there is no way to carry the case in question to the courts whatsoever. Right the acquirement to information, however, is designed as a claim towards the administrative authorities. Therefore, it puts the responsibility of doing the regarding demands on the shoulders of the administration in general. If the satisfaction is not provided, then the application to other administrative ways, like application to EBIC, or to administrative courts has been envisaged.
${ }^{6}$ However, the regarding proper way has not been defined since the implementation law and other supporting legal and administrative texts are still not prepared and accepted.

7 Since the clear compelling requirement that the lower tiers at the hierarchy of norms must be in accordance with the superior ones, though there are some limiting issues on the dissemination of the information and its acquirement (firstly due to those matters pertaining to official secret since it and its boundaries have not still been legally defined since a draft law on official secret No $1 / 484$ is submitted to the TGNA in October 21, 2011) its implementation regulation (Regulation on the Essence and Procedures regarding the Implementation of the Code on the Right to Information Acquirement) softens some issues like making it compulsory that those personnel responsible with the information acquirement to help the applicants. As it is clear that the act on the right for information acquirement Code No 4982 puts some limitations over the information acquirement starting from the its article 15 clearly defines the limitations of the regarding right.

${ }^{8}$ The Bill on the Right of Information Acquirement became a law in October 9, 2003 in TGNA with the Code No 4982, published in Official Gazette No 25269 in October $24,2003$.

${ }^{9}$ It is extremely crucial to propose that bureaucratic resistance emerges on any points in the continuum of information acquirement process even in the cases that applicants have their demands made appropriate to the procedural guidelines. Regarding to that point, the Prime Ministry Circular 2004/12 published in Official Gazette in January 2004 assures the possibilities of so-called bureaucratic resistance. These trouble making points are stated as:

"...However, there are complaints arguing that the necessary sensitivity is not shown in the applications as required by Constitution and related law articles or administrative authorities are never responding or not responding in time to those demands submitted to them as required by petition of rights, therefore the efficient usage of petition of rights is not realized...."

${ }^{10}$ Kösecik \& Karkın (2004a: 130) put forward the bureaucratic resistance $(42.6 \%)$ as the first, education and accommodation of personnel $(41 \%)$ as the second problem of possible barriers before the e-government applications in a paper aiming to evaluate the attitudes of politicians and bureaucrats of Municipality of Denizli towards e-government in particular. Similarly, Bensghir \& Akay (2006: 42) present the negative attitudes of high rank officials stemming from ignorance $(64 \%)$, deficiency in specialized personnel (55\%) and insufficiency of information technologies literacy (27\%) 
as the negative problems of Geographical Information Systems (GIS) technology usage in Turkish municipalities.

${ }^{11}$ There are three types of services in e-government web sites. First and easiest of all is giving one-way information services. This type of service is already among the characteristics of classical public administration. What e-government adds to this characteristic is the providence of infinity of documents not necessarily published on paper. Second type of services is communication services. These services include some applications as mutual e-mail between the citizens and politicians/bureaucrats, discussion forums etc. Third type is also known as online services. These services are among the ultimate aims of e-government applications aiming to the participation of citizens in the processes of decision taking. Electronic form fulfillment, online referendum and elections are among the last types of services (Kösecik and Karkın, 2004b: 110).

${ }^{12}$ It should be strictly noted that the centralist tendency of Turkish public administration stemming from historical roots, especially that of Ottoman tradition, is not as the very same centralist tendency that it is used in modern or postmodern context. According to Ortayli (2010: 23) the administrative systems of those empires of ancient and medieval times (including Ottoman Empire, 2010: 125) could not be regarded as centralist that it is used in modern context since some important necessities as the technological facilities in communication and transportation were not possible to make so-called centralist administration functional besides the lack of efficient bureaucratic structure. Therefore, it was a necessity to disperse the authority with some autonomy embedded in.

${ }^{13}$ It is generally accepted that organized actors like nongovernmental organizations (NGOs), pressure groups as professional organizations and unions take part in the public policy process. However, there must be a theoretical and practical differentiation between those organized actors as of functioning for the sake of public benefit or as of functioning for the sake of their members. The bars, the professional chambers like chambers of commerce, chambers of industry or chamber of medicine and also workers' and employers' unions should be regarded as among those of functioning for the sake of their members' interests first. For that crucial differentiation, these interest-based organizations should be regarded as of classical actors with this differentiation directly pertaining to the essence of policy making process.

${ }^{14}$ The so-called three deficits are regarded as the problems of American administration not for the other administrations. Regarding the local problems as of universal ones is a cultural characteristic of Anglo-American intellect, however, in this case, these three deficits and prescribed policies seem as universal if the policy transfer is taken into account.
${ }^{15}$ Güler (1994: 3-17) insists on her thought stating that western types of opinions and arguments are at least periodically effective in shaping the spheres and subjects of public administration. In addition, she argues that those viewpoints and products prioritizing the local do not necessarily indicate the universal. According to her, those opinions and ideas produced as a necessity of domestic needs lack the multiplier effect for taking regarded as universal. Notwithstanding this presumption, the exported theories, institutions and concepts are far away from reformulation at the local scales by purifying the exporters' ideological elements. In this context, it is essential for the politicians to take these points into effect in the policy transfer process regarded as practical and possible by international institutions.

${ }^{16}$ SPO has been transformed into the Ministry of Development by means of the decree that has the effect of law (No 641) in June 3, 2011. The decree with No 641 that has the effect of law has been published in the Official Gazette No 27958 (The Repeated Issue) in June 8, 2011.

${ }^{17}$ Regarding the e-government process in Turkey, the e-government portal, namely, www.turkiye.gov.tr is at the heart of the whole process. When roughly evaluated, it is possible to argue that the main target of all applications in this portal seems as the support the citizens with the technological tools in the very same portal rather than all public institutions having their own web sites. As guided by security and privacy drawbacks, this portal serves only for those citizens who are required to have their own personal codes (e-government ID) via system to make their transactions whatsoever.

${ }^{18}$ On an ontological basis, we are not arguing here that e-government applications imply this transformation, however if it is thought on a methodological ground, it seems quite acceptable that e-government applications provide a good functional basis for such a transformation.

${ }^{19}$ Without a doubt, it is a necessity to talk about some legal, political and administrative barriers preventing the e-government and its applicability from gaining strength and dispersion. Since this paper gives the priority to the administrative matters, bureaucratic and organizational adaptation, bureaucratic resistance, efforts of personnel for education and harmony, social resistance seem somewhat important as the administrative barriers (Kösecik \& Karkın, 2004b: 103-107).

${ }^{20}$ Since the function of public relations is among the classical principles of administration, these tools should be regarded as the modernized derivatives of this classical principle, should not be evaluated as among the participative tools. 
${ }^{21}$ Article 74 of the Turkish Constitution has been amended in September 12, 2010 by the article 8 of the Code No 5982. Regarding amendments in the Constitution have varied from "Judiciary" to the "financial and economic provisions" (Gönenç, 2010: 1). According to Gönenç (2010: 2), as a novelty in Turkish case, the institution of Ombudsman is regulated under Article 74 of the Constitution, whose title is changed as "Right of Petition, Right to Information Acquirement and Appeal to the Ombudsman". The ombudsman, who would act as a mediator between administration in general and citizens, is charged with the main function of assessing complaints about the improper functioning of the administration. Jung (2010: 5) has attracted attentions to the democratic nature of the amendments by stating that:

"The drafting of the constitutional amendments and their approval by the elected representatives of the Turkish parliament mark a decisive break with the authoritarian way in which Turkish constitutions traditionally have been put in place. The reform package was not designed by "enlightened" state elite without a popular mandate, but by the democratically elected government. Moreover, the Turkish voter had a double choice: the choice of participation (N.K.) in the referendum and the choice to say no."

22 The draft law on information acquirement submitted to the Turkish Grand National Assembly (TGNA) by 59th. Turkish Government at June 25, 2003. As being an act, it is published at the Official Gazette (No 25269) in October 24, 2004, effectuated in April 24, 2004. As quoted by Canöz (2008: 142) the articles of the Code No 4982 have been changed with the Code No 5432 in November 21, 2005.

${ }^{23}$ Since the regarding legislation year has come to end, all of the regarding draft laws proposed by both Cabinet and Member of Parliaments (MPs) have been shelved for now.

${ }^{24}$ The related Prime Ministry Circular (Nr. 2004/12) considers the right of petition as among the political rights since that right provides information acquirement function by taking responds to the questions, provides control function by complaining, and provides democratic participation by proposing.

${ }^{25}$ The draft law on information acquirement submitted to the Turkish Grand National Assembly (TGNA) by 59th. Turkish Government at June 25, 2003. As being an act, it is published at the Official Gazette (No 25269) in October 24, 2004, effectuated in April 24, 2004. As quoted by Canöz (2008: 142) the articles of the Code No 4982 have been changed with the Code No 5432 in November 21, 2005.

${ }^{26}$ The Article 4 of the law clearly states that everyone has the right to acquire information. By stating such a provision, foreigners residing in Turkey and foreign legal persons operating in Turkey have the right to benefit from the all provisions of this Act on the condition that the information requested has to be pertinent to themselves or their line of business and within the framework of the principle of reciprocity.

27 The informational nature of confidentiality of any applicants' case is surely an exception of communion. Such cases are not appropriate to share since the secret of state and corporative secrets are among the main exception categories regarding implementation of the information acquirement process at present. Those matters pertaining to the very personalities of the people must be regarded as of confidentiality and are understandable to be regarded out of dissemination.

${ }^{28}$ Public relations units of the local administrations are put into words differently among the municipalities. For example, while Istanbul Metropolitan Municipality uses "White Desk", Ankara Metropolitan Municipality prefers "Blue Desk" and Konya Metropolitan Municipality chooses "Open Gate".

${ }^{29}$ Applications via SIBIYO are reached through the website of www.sibiyo.com. At the regarding website, it is possible to make applications and make comments over the applications already made.

${ }^{30}$ The best image can be obtained at $1024^{*} 768$ by using Internet Explorer 7+, Mozilla Firefox 3+, Google Chrome, Safari browsers together with the up-to-date version of Adobe Flash Player.

31 The official strategy document of the 8th. 5-Year Development Plan (2000-2005) prepared by High Planning Council of State Planning Organization and Turkish Cabinet (approved by TGNA in June 27, 2000) states some problems of Turkish public administration such as the need for reconstruction need for an increase in public service efficiency, participative public administration, transfer of authority, need for transparency and usage of information and communication technologies in public administration. This official document proposes the transparency, participation of civil societal organizations, accountability as the possible means for solution to these problems (Şaylan, 2000: 3).

32 This article is an updated and improved version of the paper -e-Devlet ve e-Katılım için Bilgi Katılım Sistem Modeli: SİBIYYO - presented at the symposium on public administration (also printed in its proceedings) KAYSEM 5 (5. Kamu Yönetimi Sempozyumu) in May, 2010, Konya, Turkey 


\section{REFERENCES}

Akıncı, D. ve Çağıltay, K. (2005) "E-devlet Web Sitelerini Kullanmak ya da Kullanamamak: Vatandaş Açısından Kullanılabilirlik Sorunları ve Öneriler" TBD 21. Ulusal Bilişim Kurultayı, Ankara.

Akman, İ., Yazıcı, A., Mishra, A. and Arifoğlu, A. (2005) "E-Government: A Global View and an Empirical Evaluation of Some Attributes of Citizens" Government Information Quarterly, 22:239-257.

Aksoy, S. and Polatoglu, A. (2003) "The Turkish Administrative System: Concepts and Issues”, K. K. Tummala (eds.) Comparative Bureaucratic Systems, New York, Lexington Books.

Almarabeh, T. and AbuAli, A. (2010) "A General Framework for E-Government: Definition Maturity Challenges, Opportunities, and Success" European Journal of Scientific Research, 39(1):29-42.

Altan, C. (2011) "Eğitim-Siyasal Eğilim İlişkisi: Mersin Örneği” C.Ü. İktisadi ve İdari Bilimler Dergisi, 12(1):313-329.

Anameriç, H. (2004) "Bilgi Edinme Hakkı Kanunu ve Kurumsal Bilgi Yönetimi İlişkisi” Bilgi Dünyası, 5(2):168-186.

Arifoğlu, A., Körnes, A., Yazıcı, A., Akgül, M. K. ve Ayvalı, A. (2002) E-Devlet Yolunda Türkiye, Ankara, Türkiye Bilişim Derneği ve Kamu Bilgi İşlem Yöneticileri Birliği.

Bensghir, T. K. ve Akay, A. (2006) "Bir Kamu Politika Aracı olarak Coğrafi Bilgi Sistemleri (CBS): Türkiye'de Belediyelerin CBS Uygulamalarının Değerlendirilmesi” Çağdaş Yerel Yönetimler Dergisi, 15(1):31-46.

Canöz, K. (2008) "Kamuda Halkla İlişkilerin Yeni Yüzü: Bilgi Edinme Yasası” Selçuk İletişim, 5(3): 141152.

Çevik, H. H. (2004) Türkiye’de Kamu Yönetimi Sorunlar, 2. Baskı, Ankara, Seçkin Yayıncılık.

Demir, F. (2011) "Kamu Politikası ve Politika Analiz Çalışmalarının Teorik Çerçevesi” Dumlupınar Üniversitesi SBE Dergisi, 30:107-120.

DPT (2001) VIII. Beş Yıllık Kalkınma Planı Yerel Yönetimler Özel İhtisas Komisyonu Raporu, Ankara.

DPT, 8. Beş Yıllık Kalkınma Planı, http://www. dpt.gov.tr/DocObjects/Download/1969/plan8.pdf (10.09.2011).

Ergun, T. (2004) Kamu Yönetimi: Kuram, Siyasa, Uygulama, Ankara, TODAİE
French, S. and Bayley, C. (2011) "Public Participation: Comparing Approaches" Journal of Risk Research, 14(2):241-257.

Gönenç, L. (2010) "2010 Proposed Constitutional Amendments to the 1982 Constitution of Turkey" TEPAV Evaluation Note, Ankara, TEPAV.

Güler, B. A. (1994) "Nesnesini Arayan Disiplin: Kamu Yönetimi” Amme İdaresi Dergisi, 27(4):3-19.

Hassan, R. (2008) The Information Society, Digital Media and Society Series, Cambridge, MA, Polity Press.

Hu, G., Pan, W., Lu, M. and Wang, J. (2009) "The Widely Shared Definition of e-Government: An Exploratory Study" The Electronic Library, 27(6):968-985.

BEDK, 2010 Yılı Genel Raporları, http://www.bedk. gov.tr/genel-raporlar.aspx, (10.09.2011).

Jones, A., Blake, C., Davies, C. and Scanlon, E. (2004) "Digital Maps for Learning: A Review and Prospects" Computers and Education, 43:91-107.

Jung, D. (2010) "The Constitutional Referendum in Turkey: A Step Toward Democracy?" Analyze for The Center For Mellemøststudier, 1-6.

Kaptı, A. (2011) "Kamu Politika Sürecinde Klasik Yaklaşım Modeli” A. Kaptı (eds.)Kamu Politika Süreci: Teorik Perspektifler, Ankara, Seçkin Yayıncllık.

Kapucu, N. and Palabiyik, H. (2008) From Tradition to Modern Age: Turkish Public Administration, Ankara, International Strategic Research Organization Publications.

Kettl, D. F. (1998) "Reinventing Government: A Fifth Year Report Card" A Report of the Brookings Institution's Center for Public Management, Washington D.C., http://www.brookings.edu /gs/cpm/government.pdf ,(26.04.2010).

Kocacık, F. (2003) "Bilgi Toplumu ve Türkiye" Cumhuriyet Üniversitesi Sosyal Bilimler Dergisi, 27(1):1-10.

Kösecik, M. ve Karkın, N. (2004a) "Belediye Yöneticilerinin ve Meclis Üyelerinin e-Devlete Bakışı: Denizli Belediyesi Örneği” Türk İdare Dergisi, 443:119-139.

Kösecik, M. ve Karkın, N. (2004b) "Elektronik Devlet: Amaçlar, Sorunlar ve Uygulamalar" A. Yılmaz ve M. Ökmen (eds.) Kamu Yönetimi: Kuramdan Uygulamaya, Ankara, Gazi Kitapevi.

Lee, C., Chang, K. and Berry, F. S. (2011) “Testing the Development and Diffusion of E-Government and E-Democracy: A Global Perspective" Public Administration Review, 71(3):444-454. 
Löfstedt, U. (2007) "Public e-Services Research: A Critical Analysis of Current Research in Sweden" International Journal of Public Informational Systems, 2007(2): 101-112.

Mayer-Schönberger, V. and Lazer, D. (2007) "From Electronic Government to Information Government" V. Mayer-Schönberger and D. Lazer (eds.) Governance and Information Technology: From Electronic Government to Information Government, Cambridge, MIT Press.

Moon, M. J. (2002) "The Evolution of e-Government among Municipalities: Rhetoric or Reality?" Public Administration Review, 62(4):424-433.

Ortaylı, İ. (2010) Türkiye Teşkilat ve İdare Taribi, 3. Baskı, Ankara, Cedit Neşriyat.

Polatoglu, A. (2000) "Turkish Local Government: The Need for Reform" Middle Eastern Studies, 36(4):156171.

Polatoğlu, A. (2003a) "The Field Units of Turkish Central Administration" Middle Eastern Studies, 39(4):54-66.

Polatoğlu, A. (2003b) “Türk Kamu Yönetim Sisteminin Yeniden Örgütlenmesi Üzerine Düşünceler” Amme İdaresi Dergisi, 36(4):1-16.

Prime Ministry Circular on the Communication Center in Prime Ministry - Direct Access to Prime Ministry No.2006/3 (Published in Official Gazette No.26055 in November 20, 2006).

Prime Ministry Circular on the Utilization of Petition And Information Acquirement Rights No. 2004/12 (Published in Official Gazette No.25356 in January 24, 2004).
Raban, D. R., Gordon, A. and Geifman, D. (2011) "The Information Society: The Development of A Scientific Specialty" Information, Communication and Society, 14(3):375-399.

Şaylan, G. (2000) "Kamu Yönetimi Disiplininde Bunalım ve Yeni Açlımlar Üzerine Düşünceler” Amme İdaresi Dergisi, 33(2):1-21.

Sezer, Y. ve Karkın, N. (2002) "Kamu Yönetiminin Modernleşmesinde Şeffaflaşma Sorunu” Türk Iddare Dergisi, 436: 209-225.

Soykan, C. (2006) Bir Insan Hakkı Olarak Bilgi Edinme Hakkı, Yayınlanmış Yüksek Lisans Tezi, Ankara, Ankara Üniversitesi Sosyal Bilimler Enstitüsü.

TBMM (2011) Bilgi Edinme Değerlendirme Genel Raporu, Ankara, http://tbmm.gov.tr/bilgiedinme/bed_ genelrapor_2010.pdf, (02.10.2011).

Tataroğlu, M. (2007) "Kamu Yönetiminde Coğrafi Bilgi Sistemi (CBS) Teknolojisi ve Etik" Finans Politik ve Ekonomik Yorumlar, 44(513):47-61.

Wang, X. and Wan Wart, M. (2007) "When Public Participation in Administration Leads to Trust: An Empirical Assessment of Managers' Perceptions" Public Administration Review, 67(2):265-278.

Yeşilorman, M. (2006) "Siyasal Sosyalizasyon Sürecinde Sosyo-Ekonomik Faktörlerin Rolü” Bilig, 36:1-46.

Yıldız, M. (2009) "An Overview of Local E-Government Adoption and Implementation in Turkey" Reddick, C. G. (eds.) Handbook of Research on Strategies for Local E-Government Adoption and Implementation: Comparative Studies, Hershey, NY, Information Science Reference. 